\title{
Riverfront Restoration Plan Using Cipar Index: A Case Study of Gomti River, India
}

\author{
Mansi Tripathi and S. K. Singal
}

\begin{abstract}
Restoration of a polluted river front is as important as conservation of a polluted river itself because its shore line has the potential of making the conservation project self-sustainable. In the present study, an attempt has been made to study the polluted river front of a river in India. A self-sustainable restoration and development experimental plan has been prepared for the area considered in the study. This experimental plan aims at utilizing arable land strips on both sides of the river, currently deserted or encroached by rank vegetation, open wastewater drains, etc. The cost estimates have also been presented for various items and actions proposed under this study to prove its economical sustainability in the long run. The proposed plan and the existing conditions have been compared using CIPAR index to ensure increased public accessibility. It has been found that the present unsatisfactory conditions of the riverfront considered in this study can be raised to more than $90 \%$ satisfaction by implementation of the proposed plan in a period of 3 to 4 years.
\end{abstract}

Keywords: Restoration, public accessibility, sustainability, riverfront, India

\section{Introduction}

$\mathrm{W}$ Taterfront is the land confronting a water body, which may either be a marine or freshwater body.

Several waterfront development and restoration projects round the globe basically form a part of urban planning schemes, and several terms have been introduced in literature, which are used in similar context. These terms include 'waterfront regeneration' (Wood and Handley, 1999), 'waterfront revitalization' (Goodwin, 1999), 'waterfront rehabilitation' (Hoyle and Pinder, 1981), and 'waterfront redevelopment' (Gospodina, 2001). According to Goodwin (1999), waterfront restoration is initiated in response to communities' need and will to renew its waterfront. The entire process is a series of well-coordinated steps which demands involvement of the stakeholders at every stage. (Wrenn, 1983) has defined an urban waterfront as the water facing region in a metropolitan setting.

Several case studies have been presented in the past, where different approaches have been taken as per the seriousness and nature of damage being faced by the waterfront. Some of these include; primary focus on removal of metal contaminants from the shoreline using the concept of phyto remediation (Wilschut et al., 2013), use of Monte Carlo simulation for cost-benefit analysis of an urban rehabilitation project (MartínezPaz et al., 2014), use of Comprehensive Index of Public Accessibility of Riverfront (CIPAR) for assessment of a rehabilitation project for a riverfront (Che et al., 2012), integration of environmental, social as well as economic considerations by using modeling approach with the concept of Sustainability Appraisal (Kumar et al., 2013), etc. Restoration plans for waterfront mainly aim at providing a better life to the stakeholders and to increase the aesthetic and economic appeal of the river which is overlooked in front of other issues like drainage, etc. (Asakawa et al., 2004).
This paper presents a restoration plan for a river flowing through an urban setting in India and the concept of public accessibility has been applied in the form of CIPAR to measure the degree of accessibility of the restored site by the public and compared it with the degree of accessibility of the site before restoration. The term accessibility indicates the acceptance and adaptation of a place to different type of uses and population (Capron, 2002). Another socio-economic interpretation of the concept of accessibility has been defined as realization of economic, educational, environmental and recreational value of a waterfront while designing a waterfront restoration plan (Navarro, 2000). Connectivity of the entire stretch of waterfront through pathways provides added benefit by increasing accessibility (Ryan, 1998; Navarro, 2000; Asakawa et al., 2004). Public accessibility is two dimensional in nature as it includes both visual and physical corridor continuity with the surroundings (Capron, 2002). Other factors like appreciable green canopy, restrooms, clean pathways, etc. highlighting ecological and social benefits of a riverfront are also involved in the measurement of a riverfront's public accessibility (Baschak and Brown, 1995).

The CIPAR utilized in this study has been defined as the ease and freedom with which general public can utilize the services and resources offered by riverfront irrespective of their social and economic status and physical abilities. In the same reference, factors like visual continuity, spatial receptivity, amenity and ecological corridor continuity have been utilized in calculation of the final CIPAR values.

\section{Methodology}

\section{Study Area}




\section{Lucknow city}

Lucknow city, the capital of Uttar Pradesh state in India situated on the banks of river Gomti has been considered as the study area as shown in Figure 1.
November, 2000 with works like diversion of Gaughat drain away from the water intake point, cleansing of major drains, etc. It resulted in addressing about $10 \%$ of the total pollution load of the river. In the first phase,


highest priority works were accomplished and the remaining works were taken up in phase II of GoAP.

The works in second phase included a Sewage Treatment Plant (STP) of 345 MLD based on Upflow Anaerobic Sludge Blanket (UASB) technology, diversion of drains and interconnecting them to reach this STP for treatment. It also included several aspects like river front development,

Figure 1: Study area- Lucknow, the capital of uttar pradesh India

With latitude-longitude extent of $26.85^{\circ} \mathrm{N}$ and $80.92^{\circ} \mathrm{E}$ and a current population of about 2.8 million, it is one of the most populated cities in India. The river Gomti divides Lucknow into two parts. The area on the right bank is older part of the city (Cis- Gomti) while on the left is the newly developed part of the city (TransGomti). The river flows from North-West to SouthEast while the lateral slope of both sides of the city is inclined towards the river. The raw water pumping station for Lucknow water supply is situated at Gaughat, approximately $12 \mathrm{~km}$ upstream of Gomti barrage. It is worthwhile to mention here that the Gomti barrage was constructed in 1974 for ascertaining sufficient water level at Gaughat pumping station site. During the lean season (December to June), there is hardly any residual flow in river Gomti at the barrage site because all the gates of the barrage are to be kept completely down in order to maintain pond level at level $105.70 \mathrm{M}$ so that the desired water level is available at Gaughat. This study is focused on the restoration of the waterfront along this stretch of river Gomti on both, the Cis and Trans sides because it represents an ideal case of a stressed urban riverfront in a developing country.

\section{Earlier Restoration Works}

The implementation of phase I of Gomti Action Plan (GoAP) began from plantation, land acquisition etc. The project was later approved under Jawaharlal Nehru National Urban Renewal Mission(JNNURM). However, except for the establishment of the UASB plant, most of the proposed works have not seen the light of the day.

\section{Impact Analysis of Restoration Work}

\section{Comprehensive Index of Public Accessibility of Riverfront (CIPAR)}

The Comprehensive Index of Public Accessibility of Riverfront (CIPAR) (Che et al., 2012) has been used in this study. The four sub-indices of CIPAR are in synchronization with the four dimensions of Public Accessibility of Riverfronts (PAR), namely - spatial accessibility, visual accessibility, corridor continuity and amenity. Here, the first three sub-indices contribute to the measurement of PAR conditions whereas the fourth sub - index is a reflection of the social aspects of the riverfront. Each sub-index is supported by three indicators each to give an elaborate picture of the riverfront as given in Table 1.

\begin{tabular}{|c|c|c|c|}
\hline PAR dimensions & CIPAR sub- index & Indicators & Interpretation \\
\hline \multirow{3}{*}{ Spatial openness } & \multirow{3}{*}{ Spatial accessibility } & Width of open belt & \multirow{6}{*}{$\begin{array}{c}\text { Basic concept of ac- } \\
\text { cessibility }\end{array}$} \\
\hline & & Transportation types & \\
\hline & & Vulnerable groups' accessibility & \\
\hline \multirow{3}{*}{ Visual corridor } & \multirow{3}{*}{ Visual accessibility } & Bank height & \\
\hline & & River front building height & \\
\hline & & Guide system & \\
\hline \multirow{3}{*}{ Natural corridor } & \multirow{3}{*}{ Corridor continuity } & Ratio of vegetation cover & \multirow{6}{*}{$\begin{array}{c}\text { Riverfront's ecological } \\
\text { and social values. }\end{array}$} \\
\hline & & Water-oriented settings & \\
\hline & & Spatial continuity of corridor & \\
\hline \multirow{3}{*}{ Activity and comfort } & \multirow{3}{*}{ Amenity } & Facility diversity & \\
\hline & & Comfortable experience & \\
\hline & & Safety & \\
\hline
\end{tabular}

Table 1: Comprehensive Index of Public Accessibility of Riverfront 
All the sub - indices contribute evenly to the final CIPAR value; however each sub-index can also be used to draw specific conclusions. Except bank height and guide system indicators (Visual accessibility sub- index) all other indicators have been rated on a five point scale (o4) comparable with a hypothetical idealistic condition. For these two indicators, the initial visual accessibility value is decreased by 1 in case the bank height exceeds 1.2 $\mathrm{m}$ and increased by 1 when a guide system is there. The score thus achieved is multiplied by 2.5 to get the final Visual accessibility score. Table 2 gives interpretation of the final CIPAR score (Che et al., 2012).

\begin{tabular}{|l|c|c|c|c|}
\hline CIPAR value & $0-10$ & $11-20$ & $21-30$ & $31-40$ \\
\hline Public accessibility & poor & fair & Good & high \\
\hline
\end{tabular}

Table 2: Interpretation of CIPAR values

\section{Field data collection}

Eighteen different reaches of the $12 \mathrm{~km}$ stretch of Gomti river flowing through Lucknow city were assessed for this study as shown in Fig 2. The observation sites are located on both banks i.e. the Cis and Trans.



Figure 2: Observation sites of Gomti riverfront in Lucknow city

The 36 different sites were rated on a scale of $0-4$ for the different sub-indices of CIPAR, out of which the spatial accessibility and Visual accessibility parameters represented the core concept of accessibility and the parameters of Corridor continuity and Amenity are related to the economic and social significance of the riverfront. The observation sites on the North bank (Trans) have been represented as N1- N18 and those of South bank (Cis) have been represented as S1-S18. The score has been calculated for two conditions- namely, the scenario as observed on May 13, 2014 at the actual riverfront sites and second score is calculated considering the proposed experimental riverfront development plan. The summation of the scores give the final CIPAR values which have been interpreted graphically and compared.

\section{Proposed Restoration Plan}

Based on the study of impact of earlier restoration work carried out, a new riverfront restoration plan has been proposed. The proposed riverfront restoration plan includes increasing aesthetic appeal of both banks between Gaughat raw water intake and Gomti barrage. It includes the following aspects, as shown in Fig 3 and Table 3 .

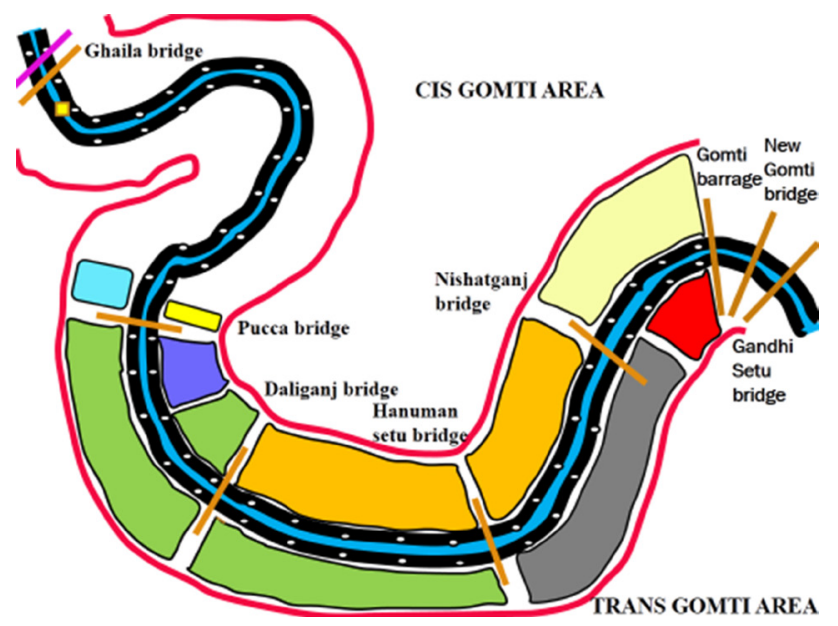

Figure 3: Overview of proposed restoration plan

\begin{tabular}{|c|c|c|}
\hline S. No. & Symbol/ Color & Meaning \\
\hline 1 & & $\begin{array}{l}\text { Concrete pathway on both sides } \\
\text { of the bank }\end{array}$ \\
\hline 2 & & Restored Kudiya ghat boat club \\
\hline 3 & & $\begin{array}{l}\text { Parking area of Recreation Cen- } \\
\text { tre }\end{array}$ \\
\hline 4 & & Gomti river \\
\hline 5 & & Main crematorium \\
\hline 6 & & Mangifera indica orchard \\
\hline 7 & & Recreation Centre \\
\hline 8 & & Projects under LDA \\
\hline 9 & & $\begin{array}{l}\text { Joggers' park / Lakshman Mela } \\
\text { ground }\end{array}$ \\
\hline 10 & & Organized dhobi ghat \\
\hline 11 & & Stone pitching \\
\hline 12 & & Bridges across Gomti river \\
\hline 13 & & New position of Gomti barrage \\
\hline 14 & & Agricultural fields \\
\hline 15 & & Solar lighting \\
\hline 16 & & Gaughat raw water intake \\
\hline
\end{tabular}

Table 3: Legend for proposed restoration plan

The details of the proposed works for riverfront restoration are given below.

1. Opening of Gomti barrage gates to allow free flow of the river to enhance the self-cleaning capacity of the river.

2. Construction of a $75 \mathrm{~m}$ long new barrage across the river, $50 \mathrm{~m}$ ahead of the Ghaila Bridge. This new location is proposed as most of the sewer drains discharge raw sewer 
just upstream to the current barrage leading to increased weed growth in the river and creation of marshes on the bank and often leading to the death of aquatic life.

3. Draw a pipeline along the earthen embankment (already present) on right bank from the water pumping station to a location upstream of the new barrage in order to draw water for consumptive purposes. Actions indicated in point 2-3 will cost about 150 million ₹.

4. Stone pitching work on both banks for $12 \mathrm{~km}$ from current barrage to Gaughat raw water intake.

\section{Right Bank}

i Restoration of Kudiya ghat boat club for river cruise facility along the length of the river. This cruise will witness several historical monuments visible from the water surface.

ii Plantation of Mango (Mangifera indica).

iii Construction of a Joggers' Park on the Lakshman Mela ground.

iv Abolition of small crematoriums, except the main crematorium lying beyond Lakshman Mela ground.

6. Left bank

i. Parking area

ii. Recreation centre

iii. Mangifera indica plantation

iv. Dharna sthal, Patang ghat, Visarjan ghat (projects under Lucknow Development Authority (LDA)) is left undisturbed.

v. Abolition of scattered washing areas and construction of an organised washing area.

7. Construction of a continuous pathway along the river on both banks. From the parking area to the washing area on North/Left bank and from Kudiya ghat boat club to Joggers' park on South/ Right bank.

8. Provision of solar lights along the constructed pathway on both banks.

All these measures will contribute to the sustainability of the restoration plan by revenue generation which will partially cover-up the capital invested and offset the operation and maintenance cost. Further details of the works are given in subsequent sections.

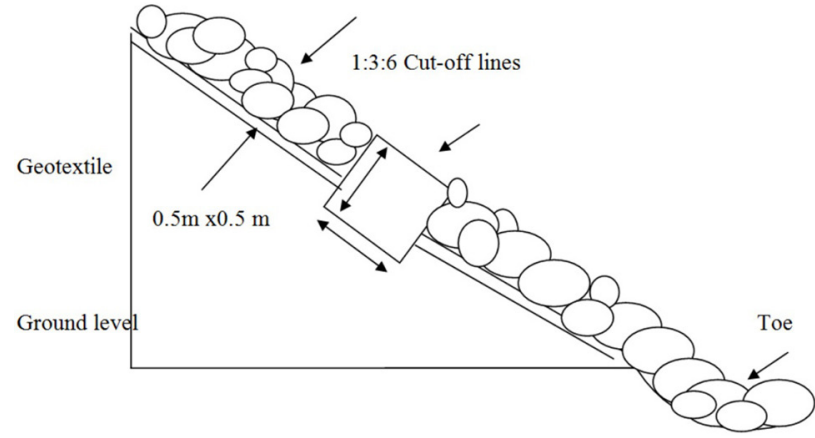

Figure 4: Cross-section of stone pitching at Gomti bank

\section{Stone Pitching Work}

It is proposed that stone pitching work should be done along the selected $12 \mathrm{~km}$ stretch. It should be 20 $\mathrm{m}$ wide and $12000 \mathrm{~m}$ long with a cross-section as shown in Fig 4. A cut-off line/ beam ( $0.5 \mathrm{~m} \mathrm{x} 0.5 \mathrm{~m}$ ) will be provided in the middle of the pitching work all along its length, so as to provide it strength and stability.
Geotextile membrane is used to provide a firm base to the structure. Toe of stone boulders should be provided at the base in order to provide stability to the slope and prevent it from crumbling down. The cost estimated for this work has been shown in Table 9.

\section{Proposal for Right/ South bank (Pucca bridge to Lakshman mela ground)}

The right bank of Gomti River will be divided into four parts for the restoration work as per the following proposed usage and the cost estimates for each have been made. Following are the area covered under these four parts;

\section{Area 1}

Location:

$\mathrm{u} / \mathrm{s}$ of Pucca Bridge

Proposal:

Restoration of Kudiya ghat boat club

\section{Area 2}

Location:

bridge

Area:

Proposal:

Between Pucca Bridge and Daliganj

\section{Area 3}

Location:

Between Daliganj Bridge to Hanuman

Setu Bridge

Area:

$62000 \mathrm{sqm}$

Proposal:

Mangifera indica plantation

\section{Area 4}

Location:

Lakshman Mela Ground

Area:

Proposal:

No. of plants

- $\quad$ For Mangifera indica orchard @ $100 / \mathrm{ha}=0.01 / \mathrm{sqm}$

- $\quad$ Field boundary plantation (Lakshman Mela Ground) (a) $83 / \mathrm{ha}=0.0083 / \mathrm{sqm}$

The number of plants calculated for the three areas is same as the number of pits required to be dug, which has been calculated and given in Table 4 .

\begin{tabular}{|c|l|l|l|c|}
\hline $\begin{array}{l}\text { S. } \\
\text { No. }\end{array}$ & Area & Unit & Land area & $\begin{array}{l}\text { No. of pits (= no. of } \\
\text { plants ) }\end{array}$ \\
\hline 1 & Area 2 & Sqm & 17006 & 170 \\
\hline 2 & Area 3 & Sqm & 62000 & 620 \\
\hline 3 & Area 4 & Sqm & 125850 & 1046 \\
\hline Total & & & & 1836 \\
\hline
\end{tabular}

Table 4: Number of plantations needed

Mangifera indica plantation has been thought of as a suitable investment as the weather conditions are best suited and in Lucknow area Mangifera indica cultivation is prevalent in all types of soils and at the same time it will also fetch good returns ("NABARD's Model Bankable Projects," 2017) (“NCPAH Report," 2017). 


\section{Lakshman Mela Ground}

The following Fig 5 and Table 5 show the typical layout and legend for Lakshman Mela Ground.

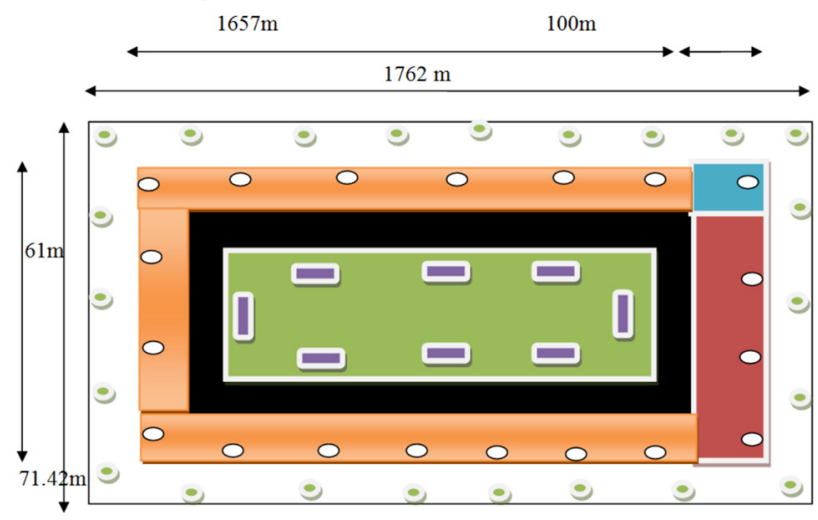

Figure 5: Layout of Joggers' Park/ Mela ground proposed at Lakshman mela ground site

\begin{tabular}{|c|l|l|}
\hline S. No. & Symbol/ Color & Meaning \\
\hline 1 & $\begin{array}{l}\text { Footpath for joggers (width } \\
=1.5 \mathrm{~m})\end{array}$ \\
\hline 2 & $\begin{array}{l}\text { Area left free for kiosks etc. during } \\
\text { public gatherings }\end{array}$ \\
\hline 3 & Parking area (concrete flooring) \\
\hline 4 & $\begin{array}{l}\text { Toilets, drinking water facility and } \\
\text { room for gardener (200 sqm) }\end{array}$ \\
\hline 5 & \begin{tabular}{l} 
Grass lawn \\
\hline 6
\end{tabular} & Benches (no. as per requirement) \\
\hline 8 & $\begin{array}{l}\text { Azatirachta indica (Neem) and } \\
\text { Butea monosperma (Dhak) as re- } \\
\text { quired }\end{array}$ \\
\hline & $\begin{array}{l}\text { Lamp Posts (no. as per require- } \\
\text { ment) }\end{array}$ \\
\hline
\end{tabular}

Table 5: Legend for Joggers' park

It is a huge patch of almost unused semi-barren land with uneven wild plantation and faces lots of soil erosion due to wind in lean season and due to water. Quite often it is used for cultural and social gatherings.

Total area for toilets, drinking water facility and room for fulltime gardener

$=200 \mathrm{sqm}$

Total concrete area in parking ground

$=6673 \mathrm{sqm}$

Area of footpath

$=5145 \mathrm{sqm}$

Area of grass lawn

$=95932 \mathrm{sqm}$

\section{Proposal for Left/ North bank (from Pukka Bridge to barrage)}

The Left/ North bank of Gomti river will be divided into four parts for the riverfront restoration work as per the following proposed usages and the cost estimates for each part follows. Following are the areas covered under these four parts;

\section{Area 1}

Location: Upstream Pukka Bridge (currently washing area)

Area $\quad$ :4750 sqm

Proposal: Parking area + drinking water and toilet facility

\section{Area 2}

Location: D/s Pukka Bridge

Area $: 32250 \mathrm{sqm}$

Proposal: Recreation Centre

\section{Area 3}

Location: Between Area 2 and Rail Bridge

Area: 20250 sqm

Proposal: Mangifera indica orchard

\section{Area 4}

Location: Between Daliganj Bridge and Hanuman Setu Bridge

Proposal: Dharna Sthal Renovation, Visarjan Ghat near Dharna Sthal and Patang Ghat

Status: Project conceived by Lucknow Development Authority (of State government)

Estimated Project cost: 78.98 million ₹

\section{Area 5}

Location: Between Nishatganj bridge and Barrage

Area: $\quad 70000$ sqm

Proposal: Organized washing area

\section{No. of plants}

For Mangifera indica orchard @ 100 /ha = 0.01/sqm Field boundary plantation (for 3 sides of the Recreation Centre and on 3 sides of the Dhobi Ghat) @ 83 / ha $=0.0083 / \mathrm{sqm}$

The number of plants calculated for the three areas are same as the number of pits required to be dug as shown in Table 6.

\begin{tabular}{|c|c|c|c|c|}
\hline S. No. & Area & Unit & Land area & $\begin{array}{c}\text { No. of pits (= no. of } \\
\text { plants) }\end{array}$ \\
\hline 1 & Area 2 & Sqm & 32250 & 200 \\
\hline 2 & Area 3 & Sqm & 20250 & 203 \\
\hline 3 & Area 5 & Sqm & 70000 & 436 \\
\hline & Total & & & 839 \\
\hline
\end{tabular}

Table 6: Number of plantations needed

\section{Parking area + drinking water and toilet facility and Recreation Centre}

Fig 6 and 7 show the layout planned for the proposed Recreation Centre and its parking area and Table 7 shows the legend for these figures. The parking area location is currently an unauthorized washing area and the location for recreation centre is currently an open unused area. The proposed recreation area will have a fountain and kiosks. It will have facility for activities like boating, zorb 
balls, mini-amphitheatre, etc.

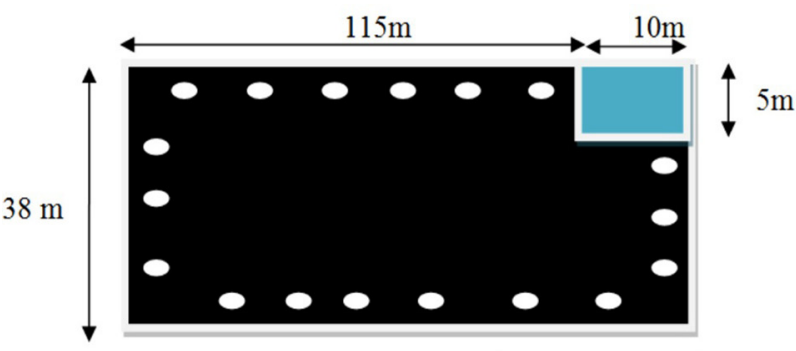

Figure 6: Layout plan for Parking area and drinking water/ toilet facility

Total area for drinking water and toilet facility $=50 \mathrm{sqm}$ Total concrete flooring area in parking ground $=4700$ sqm

Total concrete area in Recreation Centre $=31310 \mathrm{sqm}$

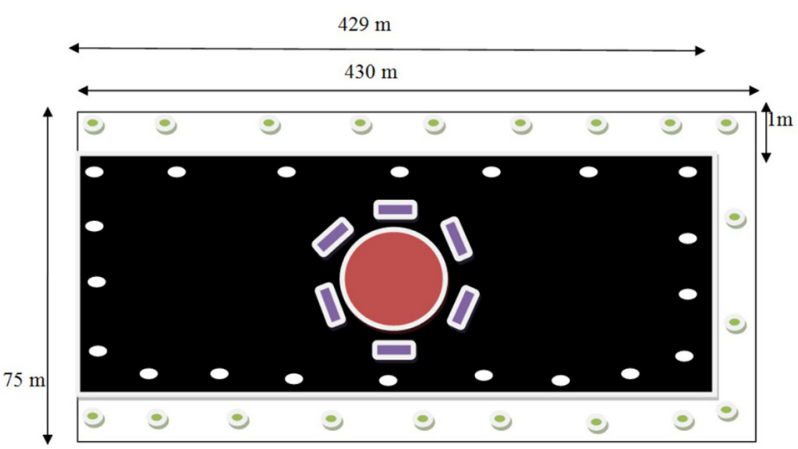

Figure 7: Layout plan for Recreation Centre

\section{Organized Washing Area}

The construction of an organized Washing Area (layout shown in Fig 8, legend in Table 8) has been proposed for an extended area of approximately 17.3 acres beyond the paper mill area and lies between Nishatganj Bridge and Gomti barrage. The organized washing area has been proposed to have a plinth area 70000 sqm with a building area of approximately 42800 sqm and drying space area of approximately $27200 \mathrm{sqm}$.

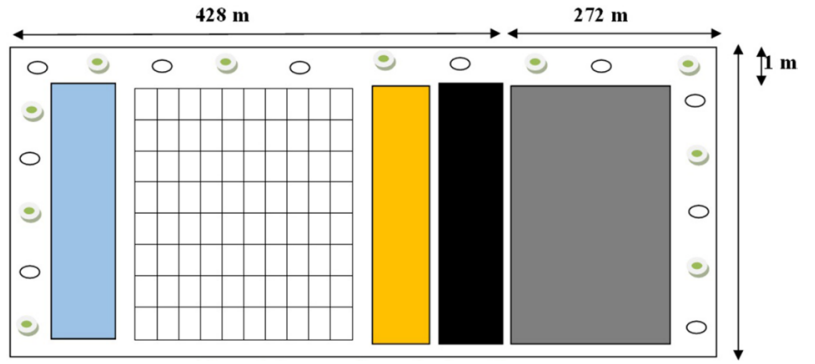

Figure 8: Layout of organized washing area

Construction of pavement and provision of lighting

It has been proposed to construct a $2 \mathrm{~m}$ wide concrete pavement on both the banks of the river for the entire length of $12 \mathrm{~km}$. This will ensure physical connectivity of the entire riverfront on each bank. Provision of solar lights at regular intervals has also been proposed at regular intervals. The provision of solar lighting on streets has been started at pilot scale at several places in
India, due to energy efficiency.

Total volume of cement concrete pavement $=2400$ cum

\begin{tabular}{|c|l|l|}
\hline S. No. & Symbol/ Color & Meaning \\
\hline 1 & & Concrete flooring \\
\hline 2 & & Space for kiosks etc. \\
\hline 3 & Fountain of 3 m diameter \\
\hline 4 & $\begin{array}{l}\text { Toilets, drinking water facility and } \\
\text { room for gardener (200 sqm) }\end{array}$ \\
\hline 5 & $\begin{array}{l}\text { Benches surrounding the fountain } \\
\text { (no. as per requirement) }\end{array}$ \\
\hline 6 & $\begin{array}{l}\text { Azatirachta indica (Neem) and } \\
\text { Butea monosperma (Dhak) as } \\
\text { required }\end{array}$ \\
\hline 7 & $\begin{array}{l}\text { Lamp Posts (no. as per require- } \\
\text { ment) }\end{array}$ \\
\hline
\end{tabular}

Table 7: Legend for layout plan of parking area and recreation center

\section{Cost Estimates}

A detailed cost estimate for the restoration works of the riverfront of river Gomti has been evaluated in the stretch considered for the study. The quantities of various works described in the previous sections have been computed. The total cost of the proposed restoration project has been estimated considering the prevailing rates of different items in the given area.

\begin{tabular}{|c|l|l|}
\hline S. No. & Symbol/ Color & Meaning \\
\hline 1 & Concrete flooring \\
\hline 2 & Boilers \\
\hline 3 & Drying area \\
\hline 4 & & Water storage tank \\
\hline 5 & $\square$ & $\begin{array}{l}\text { Washing chamber partitions (1m } \\
\text { x 1m) }\end{array}$ \\
\hline 6 & $\begin{array}{l}\text { Azatirachta indica and Butea } \\
\text { monosperma as required }\end{array}$ \\
\hline 7 & $\begin{array}{l}\text { Lamp Posts (no. as per require- } \\
\text { ment) }\end{array}$ \\
\hline
\end{tabular}

Table 8: Legend for organized washing area

\section{Results and Discussions}

The comparison of various PAR assessments using the Comprehensive Index of Public Accessibility of Riverfront (CIPAR) has been shown in Fig 9 to 12. Fig 9 shows the CIPAR values worked at 18 locations on the North bank of the river based on the restoration work carried out in the past. Similarly, Fig 10 shows CIPAR value for the 
locations on the South bank. Fig 11 and 12 shows the CIPAR values based on the proposed restoration plan on North and South bank of the river respectively.

From Fig 9 and 10, it has been found that;

\begin{tabular}{|c|c|c|c|}
\hline S. No. & Proposed Item & $\begin{array}{l}\text { Cost breakup } \\
(\text { million } ₹)\end{array}$ & $\begin{array}{c}\text { Cost } \\
(\text { million } ₹)\end{array}$ \\
\hline 1. & New barrage & & 150.00 \\
\hline 2. & $\begin{array}{l}\text { Stone pitching } \\
\text { work }\end{array}$ & & 110.00 \\
\hline 3. & $\begin{array}{l}\text { Construction of } \\
\text { pavement and } \\
\text { provision of solar } \\
\text { lighting }\end{array}$ & & 19.00 \\
\hline \multirow[t]{6}{*}{4.} & $\begin{array}{l}\text { Proposal for Right/ } \\
\text { South bank }\end{array}$ & & 6.19 \\
\hline & $\begin{array}{l}\text { Clearing rank } \\
\text { vegetation in } \\
\text { different areas }\end{array}$ & 0.98 & \\
\hline & Digging of pits & 0.03 & \\
\hline & $\begin{array}{l}\text { Mangifera indica } \\
\text { plantation }\end{array}$ & 0.27 & \\
\hline & $\begin{array}{l}\text { Plantation in } \\
\text { Lakshman } \\
\text { Ground }\end{array}$ & 0.71 & \\
\hline & $\begin{array}{l}\text { Civil work for } \\
\text { Lakshman Mela } \\
\text { ground }\end{array}$ & 4.20 & \\
\hline \multirow[t]{9}{*}{5.} & $\begin{array}{l}\text { Proposal for Left/ } \\
\text { North bank }\end{array}$ & & 502.92 \\
\hline & $\begin{array}{l}\text { Clearing rank } \\
\text { vegetation in } \\
\text { different areas }\end{array}$ & 0.61 & \\
\hline & Digging of pits & 0.01 & \\
\hline & $\begin{array}{l}\text { Mangifera indica } \\
\text { plantation }\end{array}$ & 0.07 & \\
\hline & $\begin{array}{l}\text { Plantation in } \\
\text { Recreation Centre }\end{array}$ & 0.23 & \\
\hline & $\begin{array}{l}\text { Civil works in } \\
\text { parking area and } \\
\text { recreation centre }\end{array}$ & 11.00 & \\
\hline & $\begin{array}{l}\text { Organized washing } \\
\text { area }\end{array}$ & 491.00 & \\
\hline & & & 788.11 \\
\hline & & & $\begin{array}{c}\text { Approximately } \\
790\end{array}$ \\
\hline
\end{tabular}

Note: 1 US $\$=66$

Table 9: Cost estimate for the proposed Riverfront restoration plan

1. Among the 36 observed sites, none of the riverfront sites in the current times is highly accessible (CIPAR value $>30$ ) and only 1 site (S8) on the South bank is currently in the range of good accessibility (CIPAR 21-30).

2. A majority of sites (12 in number) on the North bank fall in the range of fair accessibility (11-20), incidentally on the South bank also 12 sites fall in the same range of accessibility. Hence, among the 36 observed sites, $66.67 \%$ sites are fairly accessible.

3. Six sites on the North bank and 5 sites on the South bank fall in the range of poor accessibility (CIPAR values $0-10$ ), which accounts for $30.56 \%$ of the total number of sites.

4. These observations in the current times indicate unsatisfactory public accessibility conditions along the $12 \mathrm{~km}$ stretch of Gomti River. This means almost the entire riverfront in its current condition is either poorly or fairly accessible for public.

5. Three reaches $(13,14$, and 15$)$ out of the 18 reaches show quite different PAR conditions on the two banks. It is because the South bank is almost a complete stretch of barren land except for heavy rank vegetation, illegal dwellings and abandoned old buildings near the 13th reach and encroachments by washermen on the North bank in the 13th reach has increased the areas' vitality. For all other reaches, CIPAR values for both banks are comparable.

6. The 'Amenity' sub-index contributes least to the overall CIPAR values in all 18 reaches because the entire stretch is undeveloped and misused. 22 sites (11 North bank and 11 South bank) show zero amenity sub-index value and its average value is as low as 0.861 . This reveals minimal lighting facilities and highly unhygienic conditions due to slums, stray animals and open defecation.

7. For both the banks, maximum contribution to the final CIPAR values is given by 2 sub-indices; Corridor continuity (average score 4.139) and spatial accessibility (average score 4). The average scores are less than half of their maximum scores due to untamed vegetation, unsafe conditions for vulnerable groups due to uncontrolled growth of Water Hyacinth on the banks.

Under the proposed restoration plan shown in Fig 11 and 12 , it is seen that;

1. Out of the 36 sites, 6 sites on the North bank (N7, N8, N10, N11, N13, N16) and 7 sites on the South bank (S5, S5, S7, S8, S14, S15, S16) i.e. $36.11 \%$ of the sites have been expected to cross the mark of high accessibility with average CIPAR value 32.36 .

2. Except 2 fairly accessible sites on South bank (S12, S18), remaining sites (21 in number) are expected to fall in the 'good accessibility' zone i.e. attain CIPAR values in the range $21-30$. This shows that $58.33 \%$ sites lie above the good accessibility. It is expected that through this restoration plan the entire North bank will cross the mark of 'good accessibility'.

3. Only 2 sites on the South bank (S12 and S18) have been expected to stay in the zone of fair accessibility, with CIPAR scores 20 and 17 respectively. This is due to illegal dwellings and abandoned buildings at S12 site which if dealt with during implementation will increase CIPAR value and at S18 there is the main 
crematorium which has been left undisturbed so if it is also efficiently renovated, will increase the CIPAR value.

4. All the reaches show comparable conditions (CIPAR values) on both banks.

5. For both banks maximum contribution to the final CIPAR score is given by the sub-index 'Spatial accessibility' (average value 8.36) which is especially due to proposed construction of a pathway along the river.

6. The contribution of all four sub-indices to the final CIPAR scores is comparable for both the banks.

Comparison of conditions of the riverfront in its current condition and after the proposed restoration plan (as reflected by CIPAR values) indicate that;

1. An average of $172.28 \%$ increase is expected in the CIPAR values of all the 18 reaches in this stretch of $12 \mathrm{~km}$.

2. N14 (300\% increase) and $\mathrm{S} 13$ (375\% increase) are the sites with maximum expected \% increase in CIPAR values on the North and South banks respectively.

3. It has been found that an investment of approximately 790 million $₹$ is required for the proposed riverfront restoration plan in the study area. This project is expected to take about 3 to 4 years' time for execution. On completion, it is expected to get revenue from the developed facilities such as parking, recreation centre, Kudiya ghat boat club, etc. Plantations of Mangifera indica are expected to start giving considerable returns after 5 years of growth. This revenue will be sufficient to meet operation and maintenance requirement of facilities to make them self-sustainable.



Figure 9: CIPAR values in current condition along the North bank

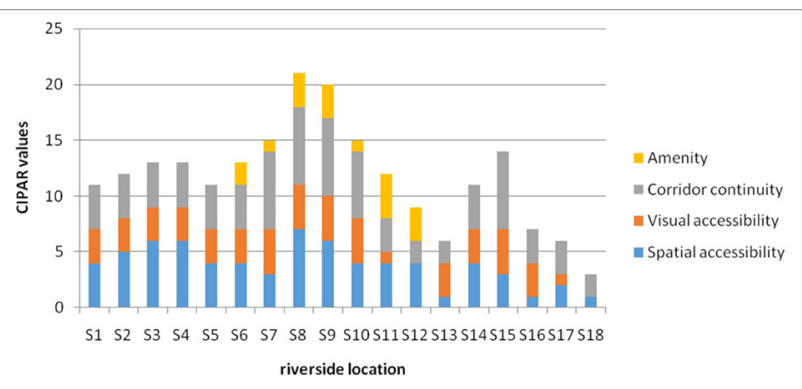

Figure 10: CIPAR values in current condition along the South bank



Figure 11: CIPAR values under the proposed restoration plan along the North bank



Figure 12: CIPAR values under the proposed restoration plan along the South bank

\section{Conclusions}

Urban riverfronts can serve as hubs of major economic, environmental, social and aesthetic prosperity of the city, provided, it is planned and maintained efficiently. The problems of a stressed urban riverfront have been addressed in this paper with the help of the case study of Gomti River flowing through the urban set-up of Lucknow city in India. Based on the present study, following conclusions are drawn.

1. As per the CIPAR values obtained for the selected 18 reaches, it is concluded that currently the entire riverfront stretch is in unsatisfactory condition in terms of accessibility which can be attributed to unhygienic condition, improper route, insufficient lighting facility, etc. The proposed restoration plan aims at rejuvenation of the riverfront, increased accessibility and socioeconomic factors considering its long-term results.

2. The implementation of the proposed restoration plan will require 3 to 4 years' time and investment of 790 million ₹. The operation and maintenance cost of the developed facilities is expected to be met by the revenue generated, hence making it a self-sustainable plan.

3. Originally $97.23 \%$ of the observed locations lie below the mark of 'fair' accessibility; however after implementation of this restoration plan, $94.44 \%$ sites are expected to lie above the mark of 'good' accessibility i.e. become 'good' or 'highly' accessible.

4. On the whole, it is concluded that specific restoration plans are needed for different riverfronts in developing countries as the problems faced vary place to place. However, advanced concepts of public accessibility and sustainability should be the basis of these plans in order to ensure their long terms success. 
Sunil Kumar Singal, graduated in Civil Engineering from University of Roorkee, India (Now Indian Institute of Technology, Roorkee) in 1983. Then he obtained M.E. degree in Earthquake Engineering and $P h$. D. from Indian Institute of Technology, Roorkee. He joined Alternate Hydro Energy Centre, University of Roorkee in 1984 as scientist. Presently he is working as Associate Professor in Alternate Hydro Energy Centre, Indian Institute of Technology, Roorkee. He has research, teaching and consultancy experience of more than 32 years in the field of Small Hydropower.

Corresponding email: sunilksingal@gmail.com

Mansi Tripathi, Graduated in Biotechnology from Amity University, Uttar Pradesh, India. Then she obtained M.Tech Degree in Environmental Management of Rivers and Lakes from AHEC, Indian Institute of Technology Roorkee. She is pursuing Ph. D. from Alternate Hydro Energy Centre (AHEC), Indian Institute of Technology, Roorkee. She is currently working as SRF at National Institute of Hydrology, Roorkee and has previously also served as a Research Officer at National Mission for Clean Ganga (Ministry of Water Resources, India).

\section{References}

Asakawa, S., Yoshida, K., Yabe, K., 2004. Perceptions of urban stream corridors within the greenway system of Sapporo, Japan. Landscape Urban Planning 68, 167-182.

Baschak, L.A., Brown, R.D., 1995. An ecological framework for the planning, design and management of urban river greenways. Landscape Urban Planning 33, 211-225.

Capron, G., 2002. Accessibility to 'Modern public spaces' in Latin-American cities: a multi-dimensional idea. GeoJournal 58, 217-223.

Cement Manufacturers' Association. (2006). Cement Concrete Roads Vs Bituminous Roads - A Cost Analysis.
Grameen Sampark.

Che et. al., 2012. Assessing a riverfront rehabilitation project using the comprehensive index of public accessibility. Ecological Engineering 40, 80-87.

Dhobi Ghat, Tripura. (2013).

Downding-Smith, E. (2012). Lighting up the streets. 1-12.

Goodwin, R. F. 1999. Redeveloping deteriorated urban waterfronts: the effectiveness of U.S. Coastal Management Programs. Coastal Management 27, 239-269.

Gospodina, A., 2001. Urban waterfront redevelopment in Greek cities. Cities 18 (5), 285-295.

Hoyle, B. S., Pinder, D. A. (Eds.) 1981. Cityport Industrialization and Regional Development. Oxford: Pergamon Press.

Kumar et. al., 2013. Integrated modeling for Sustainability Appraisal of urban river corridors: Going beyond compartmentalized thinking. Water research 47, 72217234.

Kumar, M.., 2012. Project Report on Conservation plan of river Solani, M.Tech, AHEC, IIT- Roorkee.

Martínez-Paz et. al., 2014. A probabilistic approach for the socioeconomic assessment of urban river rehabilitation projects. Land Use Policy 36, 468- 477.

NABARD's Model Bankable Projects. (2017). 1-9.

Navarro, N.G., 2000. Public waterfront access: a comparison of integrated coastal management in Canada and the United States. Master Thesis. School of Resource and Environmental Management, Simon Fraser University.

NCPAH Report. (2017). 4-6.

Ryan, R.L., 1998. Local perceptions and values for a Midwestern river corridor. Land-scape Urban Plan 42, 225-237.

Wilschut et. al., 2013. Phytoremediative urban design: Transforming a derelict and polluted harbor area into a green and productive neighborhood. Environmental Pollution 183, 81-88.

Wood, R., Handley, J., 1999. Urban waterfront regeneration in the Mersey Basin, North West England. Journal of Environmental Planning and Management 42(4), 565580.

Wrenn, D. M., 1983. Urban Waterfront Development (1st Edition) Washington DC: Urban Land Institute. 